\title{
POSITION OF THE EUROPEAN UNION IN THE GLOBAL TRADE SYSTEM
}

\author{
Mladen Jovićević \\ Maxima trejd d.o.o., Bosnia and Herzegovina \\ Željko Janjetović \\ Ministry of Foreign Affairs BiH, Bosnia and Herzegovina
}

date of paper receipt:

06.09.2017.

Orginal article date of sending to review:

20.09.2017. date of review receipt:

23.09.2017.

\section{SUMMARY}

Only a few decades ago, the main drivers of globalization were the exchange of goods and capital flows, while the global trading system of today, fuelled by rapid technological changes increasingly bases itself on knowledge. The Key events - such as the use of the Internet and the increasingly important role of the rising countries economies - have contributed to a faster global exchange, but to a new nature as well. In order to illustrate the scope of the increase, perhaps it would be the best to mention the fact that in the 1970's the share of trade in the world GDP amounted to $20 \%$, whereas today it makes about one half. On the other hand, modern products represent compounds of raw materials, components, technologies and services originating from different areas and different continents, which has globalized the products themselves. In such conditions of the market competition, imposed by globalization and liberalization, for the European Union to remain as a leader, it had to prepare a sound and well-founded foreign policy strategy. The aim of this paper is to analyse the current position of the European Union in the global trading system, instruments of foreign trade policy, goals, foreign trade and the main challenges placed before the Union.

Keywords: globalization, European Union, foreign trade, trade policy, GDP.

The International Monetary Fund defined globalization as the increasing integration of economies around the world, which enabled the increase and variety of numerous international transactions of goods and services, as well as the exchange of capital, and accelerated and generalized the technological exchange.

Pursuant to the above, we can state that the globalisation is characterized by an increasing interdependence of national economies and the world's economy, which means that the countries of the world are tied in a multidimensional network of economic, trade, social and political connections. The assumptions of global interconnection are based on the thesis imposed by the developed countries, so that rational development of economy can be perfectly accomplished on the basis of more stringent business conduct criteria, where large multinational companies are the basis and bearers of connectivity and bonding. Therefore, the basic condition for the globalization was the internationalization of the world production and trade.

The European Union, along with Chinese and American, represents the world's greatest economy, 
which accounted for $16.9 \%^{1}$ of the World's GDP (China $17,1 \%^{2}$, USA $15,8 \%$ ). Thanks to the size of its GDP at current prices (14.62 billion EUR in 2015) and the openness of its internal market that achieves export of 2415 billion EUR and import of 2188 billion EUR ${ }^{3}$, the EU plays a central role in shaping the global the trade system, primarily through its active contribution to the World Trade Organization (WTO). Economic openness has brought and will continue to bring significant benefits to the European Union, taking into account that more than 30 million jobs in the EU depend on foreign trade and that $90 \%$ of global economic growth is expected to occur outside Europe in the next 15 years $^{4}$. New economic actors and technological advances have greatly changed the structure and patterns of international trade. First of all, it includes the widespread use of information technology which enabled the trade in goods and services that were untradeable up to now.

In view of the given data, it can be said without any restriction that as for the European Union and its role in today's global market, it is clear that it represents an economic superpower. Namely, the common customs rate, single market, the 19 Member States of the Eurozone, the actions of the European Committee with authorities to conduct global trade negotiations on behalf of EU member countries, rapid economic growth as well as reduction of regional differences are only some of the many indicators of the EU's significant role in the global trade scene. The significance of the EU is brought into perspective with the following information as well:

The Union, with about half a billion of its inhabitants, has about $63 \%$ more consumers in comparison to the US.

Nineteen out of thirteen member states of the European Union have one of the world's leading currencies competing with USD and JPY. In this regard, many governments and companies have recently began taking loans in EUR, about $40 \%$ of foreign exchange transactions are done in euros, central banks are increasingly keeping their reserves in euros, whereas EUR serves as a reserve currency outside the Eurozone, especially in the Balkan countries;

About one-third of the world's largest companies are European companies mainly German, French, British, Italian and Dutch;

The European Union has grown to be the world's largest market, especially in the chemical, pharmaceutical and electronic industry, and

The EU has become a generator of economic development in neighbouring countries that do not belong to the Union.

Certainly, it should be noted that globalization and long-term effects of the global financial crisis had a negative impact on the economic results of the Union. However, compared to other industrialized economies, the EU has shown higher level of resistance to a certain aspect, which is evident from the fact that its share in the global GDP has registered a less rapid drop than, for example, the shares of Japan or the United States. This means that in times of crisis, the European Union has managed to preserve its strong position in merchandise trade, which is the strongest alongside the ones of China and the United States, while simultaneously strengthening its leading role in trading services.

1 The European Commission. (2016). Policies of the European Union - Trade. Luxemburg: Publications Office of the European Union, p.3.

2 In 2015, China overtook EU in the global GDP share.

3 European Parliament. (2017). The European Union and its Trade Partners. Downloaded from http://www. europarl.europa.eu/ftu/pdf/hr/FTU_6.2.1.pdf, on 04.06.2017.

4 European Parliament. (2017). The European Union and its Trade Partners. Downloaded from http://www. europarl.europa.eu/ftu/pdf/hr/FTU_6.2.1.pdf, on 04.06.2017, 


\section{WORLD TRADE IN GLOBALIZATION CONDITIONS}

When it comes to world trade in the conditions of globalization, it is necessary to start with the General Agreement on Tariffs and Trade - GATT and the meanings that this agreement has had onto reduction of trade customs among the signatory countries. GATT, as the first step towards globalization, among other things, contributed to strengthening the trade connections of the states that have signed the agreement. Namely, in the first decades of the previous century, the state experienced trade problems by entering into increasingly complex arrangements, which created the necessity for setting up a platform that would facilitate and regulate trade relations. Accordingly, shortly upon the end of the Second World War the representatives of 23 states in 1947 signed an international agreement in Geneva that marked the commencement of regulating trade relations between the countries in line with the principle of non-discrimination. The objective of the agreement was to aggravate the protection policy and restrictions that were most often introduced against imported goods in the past, which, in the opinion of many, significantly contributed to the outbreak of two world wars.

GATT was based on the clause on the most important benefits from which the three basic principles arose: the principle of reciprocity, the principle of liberalization and the principle of nondiscrimination. The principle of reciprocity states that the trade facilitation granted by the GATT signatories provide to one each other are to be equal for both countries. Later, this principle was mitigated for the benefit of developing countries. The principle of liberalization implies gradual reduction of customs and other restrictions, whereas the principle of non-discrimination states that double customs exemptions between two of the signatories must be applied to all the members of the GATT and are not to be increased solely by one side. General Tariff and Trade Agreement has led to the establishment of the World Trade Organization (WTO) in 1995, which, as of 2016 has 164 Member States.

The basic postulates characterizing the World Trade Organization conduct are as follows ${ }^{5}$ :

the general importance of the principle of the most favoured state,

the principle of non-discrimination,

freedom of transit:

The mentioned postulates also envisaged a large number of exceptions, embodied in free trade zones or customs in specific sectors. These exceptions have been defined and listed in the General Agreement on Trade Services (GATS), which covers: air transport services, telecommunications services, financial services and movement of labour.

The agreement by which the WTO was founded paved a path for accession of the countries that did not take part in the so-called Uruguay rounds of multilateral trade negotiations. Accordingly the new countries accessing the WTO should retroactively offer the concessions and take on the commitments specified on the date of entry into force of the Agreement.

The process of internationalization of the World's economy can be observed in three phases. In the first phase, from the founding of GATT to the beginning of the 1970s, the main role was played by global trade, while the level of internationalization was measured in the share in World export. In the second phase of internationalization, in the 1970s and the beginning of the 1980s, foreign investments had the dominant role. The role of multinational companies was significantly increased at the time, whereas the level of internationalization of an economy or a company was determined by the share of its production capacities in sales on the World market. In the second half of the 1980s occurred the third phase of the internationalization process of the World economy, called globalization, which is mainly under the influence of technology. The ability to improve, adapt and use available technologies becomes a key element of industrial competition, accompanied by new forms of investment and models of industrial organization. In order for an economy to participate in international competitions, it must rely on increasingly complex technologies, maximum flexibility, products adapted to a specific market and a wide network of suppliers. Therefore, globalization is 5 Prvulović, V. (2001). Economic Diplomacy, Belgrade: Grmeč - Economic Review, p. 31. 
nowadays perceived as a world without boundaries. Everything that is created starts to be expressed globally. This brings global products, global fashion, global consumers and even global citizens.

Therefore, globalization can even be seen as one of the stages in the development of civilization. The main factors through which globalization impacts the global trade flows are the processes of international business, formation of new product markets, constant improvement of high technologies and automated business systems, shortened product lifecycles, changing organizational structures of global companies, with the main goal of profit increase and development of new methods. Such processes are conducted in a highly complex and uncertain environment, the effects of which are increased through sudden intensification of international competition in every aspect of the global business.

Until recently, the main drivers of globalization were change of goods and capital flows. The globalization of today, triggered by accelerated technological changes, is increasingly based on knowledge. Ground breaking events, e.g. the introduction and use of the Internet and the increasingly important role of the rising economies have contributed to faster global exchange, but also to changes in the production itself. Namely, most of the products today are no longer produced in one country, but across the world. Today's products represent a set of raw materials, components, technologies and services coming from different countries, and often even from different continents. For example, the so-called "smartphones" and medical devices can be designed in China or in the United States, and assembled in Africa or in Eastern Europe from parts produced at a completely different location. Such smartphone "assembled" in China retains less than $4 \%$ of the value added in China, and more than $16 \%$ of its value added in Europe. This applies to many other products as well. In spite of that, when speaking about the export products, most of the countries are heavily dependent on the domestic value added. About $87 \%$ of the export value added from the EU is generated in the EU, whereas for China such value amounts to 76\%. Nevertheless, due to increasingly higher level of bonding the production between the EU and China in 2009 alone, more than 1.1 million jobs in the EU were dependent on Chinese exports, while in China the number of export-dependent jobs from the EU amounted to about 5, 5 million. ${ }^{6}$

All of the above enforced that the supply chains also became global, which eventually led to the increase of significance of the world trade. While in the early 1970s the share of trade in the world GDP was about 20\%, which has increased to almost half of the share nowadays. On the other hand, while traditional merchandise is generally stable, other forms of exchange, such as data flows, continue to expand exponentially. Most of estimates indicate that the value of data exchange in the European Union, alongside with an adequate framework, should increase to 739 billion euros by 2020, which corresponds to a $4 \%$ share in total GDP in the EU, which is twice as high as today. ${ }^{7}$

Essentially, globalization is a process that represents an unconditional flow of changes both in the political, economic and trade field. The benefits of globalization are in the form of global connectivity, overcoming national closure, free flow of goods, services and ideas.

There are numerous positive aspects of globalization, which affect many economic and, consequently, trade processes: ${ }^{8}$

equalization of production and entrepreneurship conditions;

harmonization of the conditions and customs regulations, foreign trade operations and foreign investments;

greater freedom of movement of goods and capital;

globalized and modernized economy, which requires a higher level of education and qualifications of the workforce;

\footnotetext{
6 The European Commission (2016) Policies of the European Union - Trade. Bruxelles. The European Commission, p.7.

7 The European Commission (2017) Reflection paper on harnessing globalisation, Bruxelles: The European Commission, p. 6.

8 Prvulović, V. (2001). Economic Diplomacy, Belgrade: Grmeč - Economic Review, p. 52.
} 
increasing the prospects for employment and opening new economic capacities; stimulation and assistance in the opening of small and medium enterprises; investment in supporting services and infrastructure (road network, ports and airports, warehouses, free customs zones ...);

increased foreign investment in profitable industries;

consistent specialization of individual economies and countries, for economic sectors and activities in which they possess comparative advantages.

Certainly, there are also negative aspects of globalization, out of which we will list only the most important ones:

artificial imposition of economic development plans by key international institutions, investor countries or multinational companies that invest in the development of certain companies, branches or sectors;

abolishing the standard economic and political sovereignty of countries;

imposing conditions through membership in international economic and political organizations, accompanied by dependence on centres of power and decision-making;

abolition of non-profitable enterprises by foreign investors, which results in social issues; reducing underdeveloped countries to the cheap labour market, without the prospect of being able to leave this position independently;

Legalization and the increasingly frequent application of economic and political sanctions in international relations, for "disobedient countries".

As it was already pointed out, globalization is a process of deeper international economic integration, which implies the rapid expansion of international trade in goods and services between countries, as well as a significant increase in the value of transfers of financial capital across national borders, including the increase in foreign direct investment by transnational companies. In recent years, talks about further liberalization of trade have been held with the main goal of extending the benefits of liberalization to poor countries. It was shown that the main issue of these conversations was agriculture. Namely, developing countries are demanding more free access to the markets of Western countries. In order for that to occur, western countries would be forced to reduce state subsidies for their agricultural products, as the subsidies and incentives make them cheaper than products from developing countries that are insufficiently subsidized or not subsidized at all.

However, regardless of the above, primarily due to digital technologies and a relatively new type of trade, e-commerce, it is expected that cross-border opportunities will continue to increase, even for the smallest companies. Today's trend is that many companies are set up "globally" and are turning to customers around the world via the Internet.

\section{FOREIGN TRADE POLICY AND GOALS OF THE EUROPEAN UNION}

\section{EU FOREIGN TRADE POLICY}

Foreign trade policy is one of the most important policies of the European Union as it determines the EU's bilateral relations with third countries and with multilateral organizations. The main goals of foreign trade policy are also defined by the Treaty on the European Union, which include the development of world trade, gradual abolition of restrictions on international trade and the reduction of customs barriers.

The EU's common trade policy is defined in Article 207 of the Treaty on the Functioning of the European Union and is within the exclusive jurisdiction of the EU. Pursuant to the given article, the EU's trade policy is based on the unified principles of EU trade relations with the world, particularly with regards to common customs rates arising from signed trade agreements, commercial aspects of intellectual property rights, foreign direct investment, levelling trade liberalization measures, establishing common export policies, as well as the use of trade protection mechanisms and the removal of trade barriers. 
The EU's trade policy can be perceived in the context of two current realities. The first is the importance of the Union itself as a major world trade participant. The second is how the globalization changes the international environment. Namely, the EU represents the world's largest economy, as the EU is the world's largest exporter and importer, the leading investor and recipient of foreign investment, as well as the world's major donor. Although only $7 \%$ of the world's population lives in the EU, it accounts for one-quarter of the global wealth measured on the basis of GDP. ${ }^{9}$

EU trade policy focuses on key partners such as the United States, Canada and Japan, although the importance is also given to large emerging economies such as the BRICS countries (Brazil, Russia, India, China and South Africa), as these countries are considered to be new drivers of the world economy due to its huge market.

In line with its trade policy, the EU has developed trade relations with various groups of countries including the countries of the European Economic Area, the Mediterranean countries, African, Caribbean and Pacific countries, as well as the countries of Southeast Europe. Likewise, part of the EU's trade policy is participation in the WTO negotiations, through which it seeks to strengthen its economic impact in the world. Within the EU's trade policy, the adoption of new measures is initiated by the European Commission and adopted by the EU Council either by a qualified majority or unanimously.

As we have already pointed out, the EU is a unique market. A unified market with the free movement of goods, services, people and capital within the borders of the EU is the foundation of the capability to create jobs through trading with other countries and regions. The responsibility for this market lies with the EU, not with the national governments. Namely, the Union itself is responsible for the trade policy of its member states, whereas the European Commission performs negotiation on their behalf. This means that no government of a Member State can individually consider a bilateral trade agreement with a non-EU partner. This allocation of responsibilities is based on EU treaties. The unanimous performance of the EU has much more weight in international trade negotiations than any of its members would have individually. Therefore, the EU is an active economic and political factor with growing regional and global interests and responsibilities.

Recently, the EU has based its foreign trade policy on three main areas of operation:

a more active role in multilateral negotiations within the WTO;

development of deepened bilateral trade relations with individual countries and regions, and applying unilateral measures, such as, granting preferential treatment to developing countries; implementing a strategy for identifying and removing specific barriers in key export markets. In line with its trade policy, the EU intents to remain the world's leading power in the future, with respect to the areas of trade, investment and providing development aid. In this regard, the EU is deeply integrated into global trade chains with the aspiration of a future primacy regardless of the emergence of new economic forces, primarily China. Therefore, the most important part of the Union's foreign trade policy is the formation of global trade flows in accordance with its own values and interests.

\section{EU FOREIGN POLICY INSTRUMENTS}

In general, foreign trade policy is managed through certain instruments (measures) affecting trade, i.e. capital and financial flows with foreign countries in order to achieve the international exchange goals. These measures constitute an essential content of foreign trade policy; they are an instrument of this policy, that is, its method of implementation and can significantly influence the commerce of business entities. They are, for the most part, an artificially caused disturbance that occurs in the development of foreign exchange.

It is well known that almost all countries in the world apply open and covert measures that hinder the free development of international foreign exchange, so that the European Union is no exception

9 The European Commission. (2016). Policies of the European Union - Trade. Luxemburg: Publications Office of the European Union, p.3. 
in that respect. Which foreign policy instruments in certain countries or international organizations will be applied depends on the level of development of the national economy and the foreign trade environment of the country in question.

The following items may occur as the foreign policy instruments:

Customs;

non-tariff barriers i

international agreements on free trade, etc.

More generally, the basic instruments of implementing the EU trade policy are: common external customs, trade protection mechanisms, i.e. anti-dumping, anti-subsidy policy or protective measures, as well as the Trade Barriers Regulation. Within the framework of trade policy, the EU develops instruments for accessing the third-country markets, primarily through the establishment of trade barriers and the manner of their elimination, as well as through the development of "special relations", i.e. preferential agreements and use of allowed deviations in respect of the most favoured nation principles within the WTO.

It is hereby necessary to point out that the trade policy of the EU should be viewed in the context of two current realities. The first is the importance of the EU as a key factor at the world trade scene, with the second being globalization and its reflection onto changes in the international environment.

The main instrument of the EU foreign policy are customs. Namely, the European Union, at that time named the EEC, was founded in 1958 as a customs union. This assumed that, apart from the abolition of customs duties in the trade between Member States, the common customs tariff applicable in trade with non-member countries should be adopted, which implied the detailed harmonization of the trade interests of all Member States.

According to the World Bank data , customs duties on imports of products into the EU were about $3 \%$ at the end of the 20th century ${ }^{10}$, with the exception that customs duties on imports of agricultural products into the Union were higher (about 8\%), whereas customs duties on imports of industrial products were significantly lower. It should be noted here that these data are not in compliance with the data provided by the World Trade Organization, based on which considerably higher customs rates were applied. The significant reduction in customs duties imposed by the EU has been influenced by the results of negotiations in the GATT rounds. Due to a significant reduction in customs duties, this foreign trade policy slowly lost its significance, with non-tariff barriers used for protection from external competition imposed themselves as a dominant instrument. Traditional non-tariff barriers, which generally include quantitative constraints, agreements on projected export restrictions, levies, anti-dumping measures, subsidy compensation measures, public procurements and measures of obligatory domestic content, represent the most important segment of non-tariff barriers to the Union today. The structure of these barriers is still dominated by quantitative restrictions, although price measures are a significant barrier to trade.

The application of quotas, as the most significant quantitative restriction, is particularly evident in the textiles and agriculture sectors and in EU trade with developing countries. For each developing country, the relevant directives provide for appropriate quotas for imports into the EU market.

The EU often applies agreements on a "voluntary" restriction that is made in order to regulate EU trade with developed countries regulating trade in the automobile, steel or textile industry. The most famous agreement of this type is the one „signed by the EU and Japan in 1992, regulating the trade in cars." 11

Anti-dumping measures are the most widely used instrument of the EU's common foreign trade policy. These measures are meant to protect EU companies from dumping by foreign companies. Namely, at the request of an EU company, the EU authorities initiate an anti-dumping investigation to determine if there is any dumping and if there is any damage caused. This investigation is in

$10 \quad$ World Bank, World Development Indicators, Washington D.C.

11 Bijelić, P. (2003). Foreign Trade Policy Model of the European Union. Journa: Economic Annals No. 136.

Belgrade: Faculty of Economics, p.128 
compliance with the WTO regulations, but also with the regulations of the Union itself which foresees the so-called EU interest test ${ }^{12}$ which implies that anti-dumping measures cannot be taken if they are contrary to the interests of the Union, which means that all economic factors must be taken into account. In this case, the possibility of applying the lower customs rule is also envisaged, which implies that the EU authorities can apply an anti-dumping duty lower than the dumping margin.

One of the instruments of the EU's common trade policy is the production subsidies through which the Union authorities encourage agricultural production in the Union. For years, the largest beneficiary of these premiums paid from the Union budget have been the agricultural producers in France. Subsidies are financial grants to companies that produce a particular type of goods, thus improving the competitive position.

On the contrary, the EU protects itself from subsidized products originating from other countries through the implementation of compensatory measures, which are called anti-subsidy measures in the Union.

The EU also has some specific instruments of foreign trade policy, the most common of which are the rules governing the regulation of trade barriers imposed on European companies in third markets.

In the area of technical barriers to trade, the EU is a member of the WTO who has introduced the most new standards (1300 of them, solely in the period from 1995 to 2000). These standards and technical regulations represent significant non-tariff barriers to trade.

When customs duties, as instruments of foreign trade policy, lost their significance due to a significant reduction, while traditional non-customs and technical barriers to trade became regulated by WTO rules, administrative barriers to trade emerged as a significant obstacle. They represent all obstacles that arise from the application of administrative regulations and procedures and which have a significant negative impact on the performance of foreign trade. In this regard, the EU aims to, in cooperation with third countries and through other regional economic integrations, eliminate administrative barriers in mutual trade. As for the area of regulation of administrative barriers to trade, the most important ones are the Customs Cooperation and Mutual Assistance Agreements, ${ }^{13}$ signed by the EU with Canada, the Republic of Korea and the United States. Likewise, the EU Accession Agreements signed by most of the countries of Eastern and Central Europe, provided for harmonization of customs procedures of those countries with EU rules. Similar provisions are also contained in the trade cooperation agreements concluded by the EU with Russia, Morocco, Tunisia, Israel and Turkey.

\section{OBJECTIVES OF THE EU'S FOREIGN TRADE POLICY}

The initial objectives of the foreign trade policy of the European Union have been defined by the EC Treaty and concerned the improvement of the development of world trade, gradual abolition of restrictions on international trade and the reduction of customs barriers. These objectives have been largely achieved in the past, and the globalization of the market has imposed new goals. In this regard, the basic objectives of the EU's foreign trade policy in the coming period could be reduced to the following:

opening new markets for goods and services;

Creation of a global system for fair and open trade:

Increase of protection and investment opportunities;

cheapening of trade by reducing customs duties and the accumulated bureaucracy;

Acceleration of trade through easier customs clearance procedures and setting new harmonized

12 Community interest test

13 Customs Cooperation and Mutual Assistance Agreements 
technical and sanitary standards;

raising safety through clear and regulated rules of intellectual property, market competition and public procurement;

Support to sustainable development by fostering transparency and dialogue, particularly with respect to social and environmental issues.

Finally, we should add that the EU uses its foreign trade policy to promote some other goals primarily concerning the creation of a favourable environment in the fight against climate change, the improvement of working and health conditions, and the establishment and improvement of safety standards for all products.

\section{FREE TRADE AGREEMENTS}

EU Member States share a unified market, have one external border and conduct one trade policy, which means they can freely trade amongst one another without paying customs or fees. It further means that they act harmoniously in the global market. The concerted action has led the EU to be the world's largest exporter of industrial products and services today, but it is also the largest export market for more than a hundred countries. Accordingly, EU trade represents almost one fifth of the world's total trade. Such an international economic position enabled the EU to decisively influence the shaping of trade rules and regulations, and setting standards for goods and services.

The Union's trade policy is an integral part of its broader strategy planned up to 2020 to encourage employment and create a more modern, more successful and sustainable economy. In the given strategy, the importance of free trade is particularly stressed. Free trade is more important than before for economic development and creation of new jobs, as about two thirds of raw materials and semi-finished products are imported. Any limitation of their flows or an increase in import costs would not have the desired effect, especially as the direct consequence would be to increase costs and reduction of the competitiveness of European companies and products both on the domestic and international markets.

The international economic presence of the EU at the global trade scene is based on the removal of trade restrictions and customs barriers (liberalization of trade), in line with the goals of the Treaty of Rome. These activities served as a framework for the development of a common EU trade policy in accordance with which the Union has, over time, developed a complex network of multilateral and bilateral trade networks and agreements. Most of the agreements are based on: geographical proximity (agreements with Eastern European and Mediterranean countries), close colonial ties or the principle of convenience (agreements with the United States and Japan). It is interesting to note that free trade agreements before 2006 made less than a quarter of EU trade, only for the EU to have 28 trade agreements signed by $2012 .{ }^{14}$

Agreements signed by the EU differ depending on the level of objectives and capacities of the country or group of countries which the negotiations were held with. It is clear that there is no unique approach that would fit everyone as many partners of the EU have different interests, which is why the content of each agreement is "tailored" to each specific situation. For example, Free Trade Agreements with developed and emerging economies are focused on economics and are generally based on the reciprocal market opening. On the other hand, the Economic Partnership Agreements with African, Caribbean and Pacific countries combine trade and development goals. As an example of such a recent agreement, we may take the Association Agreement between the EU and Central America (Costa Rica, El Salvador, Guatemala, Honduras, Nicaragua and Panama) signed in June 2012.

A typical free trade agreement encompasses various sectors and issues, and sets deadlines for

14 As per: The European Commission (2016). Policies of the European Union - Trade. Luxemburg:

Publications Office of the European Union 
reducing customs duties on individual products. The modern EU trade agreements include certain non-tariff issues, ranging from intellectual property to public procurement. They contain various provisions, e.g. in terms of the rules of origin in order to determine which products are subject to reduced rates of customs duties, and to which of them such tariffs are completely abolished. Free trade agreements strengthen the EU rule-based system exceeding beyond the WTO framework, therefore embedding certain provisions of the agreement into international contractual relations for the purpose of protecting trade and investment.

Finally, we may add that the Free Trade Agreements are the backbone of numerous association agreements as well. In addition, the EU is linked with some of its neighbours in the Customs Union (Andorra, San Marino and Turkey), with the following free trade agreements in force in Europe: the Faroe Islands, Iceland, Norway and Switzerland, as well as with the countries of the Southern Mediterranean: Algeria, Egypt, Israel, Jordan, Lebanon, Morocco, the Palestinian Authority, Syria and Tunisia. For the topic at hand, it is particularly important to emphasize that in addition to the Stabilization and Association Agreement with the Western Balkan countries, the EU applies a system of autonomous trade privileges with the Former Yugoslav Republic of Macedonia, Albania, Montenegro, Bosnia and Herzegovina, Serbia and UNMIK / Kosovo.

\section{POSITION OF THE EU IN INTERNATIONAL TRADE EXCHANGE}

Ever since the World War II, the EU, alongside with the United States, has played a key role in the development of the international trading system. The very original purpose of the Union, as well as of the GATT (and later the WTO), was the abolishment of customs barriers and support to the development of trade among its member states, so that it can be said that the EU has always been one of the main advocates of a functioning international trade founded on the rule of law. The EU's common trade policy is one of the areas over which the EU has full and direct competence. In other words, when operating within the WTO, the EU acts as a single entity represented by the Commission, not by its Member States. This practically means that the Commission negotiates trade agreements on behalf of all 28 Member States and defends the interests of the EU before the WTO Dispute Settlement Committee. The EU also strives to promote the multilateral framework for trade negotiations within the WTO, which aims to complement and potentially upgrade bilateral negotiations. However, the fact that some trading partners have turned to bilateral negotiations forced the EU to partially reassess its long-standing strategy and return to regional and bilateral negotiations. Such an active approach to EU issues related to international trade is linked to the fact that the EU today represents the world's largest economy: it has the largest foreign trade, that it is the largest exporter and importer of goods and services, it is the leading investor and recipient of foreign direct investment and the main aid donor. In order to support such fact, the following table contains the GDP of the ten most important world economies in 2014. 
Table 1 GDP of ten most important world economies in $2014 .^{15}$

\begin{tabular}{|l|r|r|r|}
\hline & $\begin{array}{l}\text { GDP in current prices in } \\
\text { billions of euro }\end{array}$ & \% of world GDP & $\begin{array}{l}\text { Gross public debt \% } \\
\text { GDP }\end{array}$ \\
\hline EU & 13.496 & 17,1 & 88,1 \\
\hline USA & 13.058 & 15,9 & 104,8 \\
\hline China & 7.796 & 16,6 & 41,1 \\
\hline Japan & 3.464 & 4,4 & 246,2 \\
\hline Brazil & 1.766 & 3,0 & 65,2 \\
\hline India & 1.544 & 6,8 & 66,1 \\
\hline Russia & 1.401 & 3,3 & 17,8 \\
\hline Canada & 1.344 & 1,7 & 87,9 \\
\hline Australia & 1.086 & 1,0 & 33,9 \\
\hline South Korea & 1.062 & 1,6 & 36,0 \\
\hline World, total & 58.163 & & \\
\hline
\end{tabular}

The table clearly shows the EU's visible importance for the global wealth measured by GDP. In 2014, the EU was the largest trading partner for 59 countries in the world. For the sake of comparison, in that particular year, China was the largest trading partner for 37 countries, and for the United States only for 23 countries. In the same year, European foreign trade in goods and services accounted for $34 \%$ of EU GDP, which is about 4 percentage points higher than the US.

The following table shows exports, imports and total turnover of EU goods and services in the period 2010-2015 in billions of euros.

Table 2 Export, import and trade of the EU in goods and services in the period 2010-2015.

\begin{tabular}{|l|l|r|l|l|l|l|l|l|l|}
\hline & \multicolumn{4}{|l|}{$\begin{array}{l}\text { Export from the EU } \\
\text { in billion euro }\end{array}$} & \multicolumn{4}{l|}{$\begin{array}{l}\text { Import in the EU } \\
\text { in billion euro }\end{array}$} \\
\hline & Goods & Services & Total & Goods & Services & Total & Goods & Services & Total \\
\hline 2015 & $1.791,50$ & 811,20 & $2,602.70$ & $1.728,10$ & 660,50 & 2.388 .60 & $3.519,60$ & $1.471,70$ & $4.991,30$ \\
\hline 2014 & $1.702,00$ & 764,90 & $2.466,90$ & $1.688,80$ & 602,00 & $2.290,80$ & $3.390,80$ & $1.366,90$ & $4.757,70$ \\
\hline 2013 & $1.736,30$ & 719,60 & $2.455,90$ & $1.684,20$ & 544,10 & $2.228,30$ & $3.420,50$ & $1.263,70$ & $4.684,20$ \\
\hline 2012 & $1.684,30$ & 680,70 & $2.365,00$ & $1.795,10$ & 517,80 & $2.312,90$ & $3.479,40$ & $1.198,50$ & $4.677,90$ \\
\hline 2011 & $1.554,20$ & 615,30 & $2.169,50$ & $1.726,70$ & 479,40 & $2.206,10$ & $3.280,90$ & $1.094,70$ & $4.375,60$ \\
\hline 2010 & $1.353,20$ & 569,50 & $1.922,70$ & $1.529,40$ & 461,60 & $1.991,00$ & $2.882,60$ & $1.031,10$ & $3.913,70$ \\
\hline
\end{tabular}

Source: European Commission DG (2016) Trade Statistical guide 2016, p. 14-17.

It is evident from the table that there is a trend of growth of exports from the EU, both in goods and services turnover, while the most intensive import of goods was in 2012. When the services are concerned, there is a general trend of growth in the observed period, regardless of whether it was an export or import of services. Furthermore, it is easy to conclude from the table that total turnover from of goods and services maintains its growth on a yearly basis, as one of the goals of EU trade policy, which represents a consequence of further liberalization of the market.

If we look only at the goods turnover of the EU in relation to the total world turnover, from the following table it can be seen that the EU's turnover in the observed six years makes up about 15\% of the world's turnover, making the Union a world trade leader, with the exception of 2013 when the title was handed over to the United States, that is 2015, when China took the leading role, which is visible from the following table.

15 According to: The European Commission. (2016). Policies of the European Union - Trade. Luxemburg: Publications Office of the European Union, p. 3. 
Table 3 Total goods turnover of the EU in relation to the world in the period 2010 - 2015 in billion of euros

\begin{tabular}{|l|r|c|c|c|c|c|c|c|c|c|c|c|}
\hline & 2015 & 2014 & 2013 & 2012 & 2011 & 2010 & & & & & & \\
\hline & & $\%$ & & $\%$ & & $\%$ & & $\%$ & & $\%$ & & $\%$ \\
\hline EU & $3.519,6$ & 14,72 & $3.390,8$ & 14,82 & $3.420,5$ & 14,88 & $3.479,4$ & 14,90 & $3.280,9$ & 15,71 & $2.882,6$ & 15,84 \\
\hline USA & $3,436.6$ & 14,37 & $3.035,8$ & 13,27 & $3.572,3$ & 15,54 & $3.021,7$ & 12,94 & $2.692,9$ & 12,89 & $2.449,8$ & 13,46 \\
\hline $\begin{array}{l}\text { CHI- } \\
\text { NA }\end{array}$ & $3,566.4$ & 14,92 & $3.238,0$ & 14,15 & $3.131,6$ & 13,63 & $3.009,9$ & 12,89 & $2.616,4$ & 12,53 & $2.243,3$ & 12,33 \\
\hline Russia & 481.7 & 2,01 & 606,6 & 2,65 & 651,0 & 2,83 & 673,0 & 2,88 & 607,6 & 2,91 & 489,7 & 2,69 \\
\hline World & $23,910.9$ & & $22.879,3$ & & $22.982,8$ & & $23.350,1$ & & $20.889,4$ & & $18.199,8$ & \\
\hline
\end{tabular}

Source: European Commission DG (2016) Trade Statistical guide 2016

We have already stressed that the numerous free trade agreements and trade privileges that the EU has signed with various countries are of great importance for the growth of total foreign trade. In recent times, when trade was restricted to movement of physical goods from one part of the world to another, negotiations were conducted almost exclusively on customs and quotas. Nowadays, when state economies are more sophisticated, trade policy encompasses a wide range of activities and practices. These include services, intellectual property rights, foreign direct investments, standards for plant and animal health, as well as for industrial and non-industrial goods, licensing practices and domestic taxes. The following table and diagram, according to the European Commission's report on trade, show the largest foreign trade partners of the European Union in 2015 with respect to the trade in goods. Foreign direct investments and trade in services are not included in the data given.

Table 4 The 10 largest trading partners of the European Union in $2015^{16}$

\begin{tabular}{|l|r|r|r|r|r|r|}
\hline Country & Import & \multicolumn{1}{|l|}{$\%$} & \multicolumn{1}{l|}{ Export } & \multicolumn{1}{l|}{ FTA } & \multicolumn{1}{l|}{} \\
\hline USA & 246,211 & $14.27 \%$ & 369,549 & $20.66 \%$ & 615,760 & $17.52 \%$ \\
\hline China & 350,257 & $20.31 \%$ & 170,399 & $9.52 \%$ & 520,656 & $14.82 \%$ \\
\hline Switzerland & 102,299 & $5.93 \%$ & 150,833 & $8.43 \%$ & 253,132 & $7.20 \%$ \\
\hline Russia & 135,876 & $7.88 \%$ & 73,905 & $4.13 \%$ & 209,781 & $5.97 \%$ \\
\hline Turkey & 61,574 & $3.57 \%$ & 78,959 & $4.41 \%$ & 140,533 & $4.00 \%$ \\
\hline Norway & 74,313 & $4.31 \%$ & 48,867 & $2.73 \%$ & 123,180 & $3.51 \%$ \\
\hline Japan & 59,726 & $3.46 \%$ & 56,572 & $3.16 \%$ & 116,298 & $3.31 \%$ \\
\hline South Korea & 42,327 & $2.45 \%$ & 47,882 & $2.68 \%$ & 90,209 & $2.57 \%$ \\
\hline India & 39,449 & $2.29 \%$ & 37,919 & $2.12 \%$ & 77,368 & $2.20 \%$ \\
\hline Brazil & 30,879 & $1.79 \%$ & 34,588 & $1.93 \%$ & 65,467 & $1.86 \%$ \\
\hline Others & 581,956 & $33.74 \%$ & 719,590 & $40.22 \%$ & $1,301,546$ & $37.04 \%$ \\
\hline & & & & & & \\
\hline Total & $1,724,867$ & & $1,789,063$ & & $3,513,930$ & \\
\hline
\end{tabular}

By analysing the above table, we can conclude that the main foreign trade partners of the European Union are the United States, China, Switzerland and Russia to which it accounts for 45,515 of the EU total trade of goods.

The United States are the most important foreign trade partner of the European Union. With the aim of increasing the trade volume, the most ambitious trade negotiations between the United States and the EU, known as the Transatlantic Partnership for Trade and Investment (TTIP) negotiations

16 Source: Eurostat in The European Commission (2016) Policies of the European Union - Trade. Luxemburg: Publications Office of the European Union, p. 6. 
began in June 2013. The achieved strategic partnership should further strengthen the links of the Union and its largest export market, but also serve for high-quality check of trade rules on a global level. Since the average customs duties are about $4 \%$, the easiest method to achieve progress is by removing non-customs barriers.

China is the second largest EU partner, while EU is China's largest partner. At the end of 2013, the Union began negotiations with China on a comprehensive investment agreement that would allow for gradual liberalization of investments and mutual removal of restrictions on investors in both markets.

As for Russia, it is necessary to emphasize that the EU is Russia's most important trade partner, comprising about a half of Russian exports and imports. After joining the WTO in 2012, Russia reduced import duties, thus opening the door for resolving bilateral issues with the EU. However, the situation in Ukraine and the sanctions imposed on Russia have recently significantly affected the volume of trade between the EU and the Russian Federation.

\section{CONCLUSION}

Globalization represents the growing economic dependence of all the world's countries, which has enabled the increase and diversification of the number of international transactions of goods and services, the exchange of capital, and accelerated and generalized the technological exchange.

Thanks to the volume of its GDP and the openness of its internal market, the EU has a leading role in shaping the global trading system, primarily through its active contribution to the creation of the World Trade Organization.

The EU trade policy focuses on key partners such as the United States, Canada and Japan, although the importance is given to large emerging economies such as the BRICS countries (Brazil, Russia, India, China and South Africa), as these countries are considered to be the new drivers of the world economy due to its enormous market.

The Union's modern trade policy is an integral part of its broader strategy planned up to 2020 for the purpose to incitement of employment and creation of a more modern, more successful and sustainable economy. In the given strategy, the importance of free trade is particularly emphasized. The most important part of the Union's foreign trade policy is the moulding of global trade flows in accordance with its own values and interests.

In accordance with its own trade policy, the EU today represents the largest world economy, has the largest foreign trade, is the largest exporter and importer of goods and services, but also the leading investor and recipient of foreign direct investments as well as the main aid donor. 


\section{LITERATURE}

1. Bijelić, P. (2003). Foreign Trade Policy Model of the European Union (orig. in Serbian: Model spoljnotrgovinske politike Evropske unije). „Economic Annals“Journal No. 136. Belgrade: Faculty of Economics

2. The European Commission (2016). Policies of the European Union - Trade. Luxemburg: Publications Office of the European Union,

3. The European Commission (2017) Reflection paper on harnessing globalisation, Bruxelles: The European Commission, p. 6.

4. European Parliament. (2017). The European Union and its Trade Partners. Downloaded from http://www.europarl.europa.eu/ftu/pdf/hr/FTU_6.2.1.pdf, on 04.06.2017.

5. Prvulović, V. (2001). Economic Diplomacy (orig. in Serbian: Економска дипломатија), Belgrade: Grmeč - Economic Review,

6. Economic Annals No. 136. Belgrade: Faculty of Economics, University of Belgrade.

7. World Bank, World Development Indicators, Washington D.C. 